\title{
Discussion: Design of the Dubai Metro light rail viaducts - substructure and superstructure
}

D. A. Smith, C. R. Hendy and N. R. Hewson

\section{Contribution by Norman D. Tickner, Parsons Brinckerhoff, Australia}

I refer to the papers by Smith et al. (2009) and Smith and Hendy (2009) on the Dubai Metro light rail viaducts.

My question relates to design and detailing of the structures for control of stray currents and corrosion prevention, as I understand that the rolling stock is powered by a $750 \mathrm{~V}$ d.c. third rail system.

\section{Authors' reply}

The authors thank the contributor for his kind remarks and for raising the query of stray currents. The rolling stock for the Dubai Metro is indeed powered by a $750 \mathrm{~V}$ d.c. propulsion system by way of a third rail, and the project specification required the contractor to mitigate the deterioration of buried metallic structures as a result of stray currents.

While stray currents cannot be eliminated, the metro system is designed to minimise and control their flow and thus control the corrosion risk to the concrete structures. This was achieved by designing suitable details to ensure that the stray current is collected at deck level and is suitably isolated from the substructure. Within the decks, longitudinal segment reinforcement is connected between segments with additional tack-welded bars in pockets subsequently in-filled with concrete. At the ends of simply supported decks, longitudinal deck reinforcement is connected by way of a cable link (which for some spans is removable for future testing and monitoring). Prestressing tendons, continuous through the segments in steel ducts, are connected to the reinforcement at their anchorages by way of further cable links. Approximately every six spans, the reinforcement is connected to the stray current collector cable, which runs longitudinally at track slab level.

Stray current test points are incorporated in selected pier locations, bonded to reinforcement cages within the pier to monitor the effectiveness of the isolation concept.

\section{REFERENCES}

Smith DA, Hewson NR and Hendy CR (2009) Design of the Dubai Metro light rail viaducts - superstructure. Proceedings of the Institution of Civil Engineers, Bridge Engineering 162(2): 55-62, doi: 10.1680/bren.2010.162.2.55.

Smith DA and Hendy CR (2009) Design of the Dubai Metro light rail viaducts - substructure. Proceedings of the Institution of Civil Engineers, Bridge Engineering 162(2): 63-74, doi: 10.1680/bren.2010.162.2.63.

\section{What do you think?}

To discuss this paper, please email up to 500 words to the editor at journals@ice.org.uk. Your contribution will be forwarded to the author(s) for a reply and, if considered appropriate by the editorial panel, will be published as discussion in a future issue of the journal.

Proceedings journals rely entirely on contributions sent in by civil engineering professionals, academics and students. Papers should be 2000-5000 words long (briefing papers should be 1000-2000 words long), with adequate illustrations and references. You can submit your paper online via www.icevirtuallibrary.com/content/journals, where you will also find detailed author guidelines. 